\title{
Information Dissemination Effects To P0rovision of Land for Railway Lines In Relationship with the Knowledge, Attitude and Behavior of the Land Owners in Barru Regency, South Sulawesi - Indonesia
}

\author{
Hafied Cangara \\ Department of Communication, Hasanuddin University \\ Ahmad Supriyadi \\ Department of Communication, HasanuddinUniversity
}

Aminuddin Salle

Faculty of Law, Hasanuddin Univeristy

\begin{abstract}
The aims of the research were to determine the effect of information dissemination of land acquisition of railways on knowledge, attitude and behavior of the land owners in Barru, and to determine the factors that affect the process of land release for railway construction in Barru. This study was conducted in Barru with quantitative approach. Population of the study were 899 land owners around the railway in Barru. Sample were 100 people selected with Slovin formula. Data were analyzed with linear regression analysis. Results of the research indicated that the influence of information dissemination conduct of the land owners through television was $3.9 \%$, newspaper $5.8 \%$, online media $7.8 \%$, interpersonal communication $26.04 \%$, and group communication $21.5 \%$. Interpersonal communication had the greatest effect among the five communication channels. Factors influencing the process of land release for the railway construction in Barru were public interest, government programs, religious knowledge, the compensation value and a sense of pride the railway presence in Barru.
\end{abstract}

Keywords: information dissemination , media, knowledge, attitude, behavior, land owner

\section{INTRODUCTION}

One indicator of the success of a country's development is the development of transportation. Because transport plays an important role in economic development, social, and defense of a country. Indonesian transport sector development geared toward creating a transport system that is reliable, powerful and organized effectively and efficiently in supporting the mobility of goods, people and services to support the distribution pattern of national and regional development.

To realize the achievement of the national transportation system that is effective and efficient, required the provision of public transport is massive, secure, convenient, fast, smooth, and cheap. It is intended to address one of the major problems in the movement of people and goods is the traffic jams that occur almost every major city in Indonesia, especially with increasing vehicle uncontrollable car for the last two decade. It required a means of transportation other than safe and smooth, well-efficient, energy-efficient use of space, low 
pollution levels, and has high security. And one means of transportation are eligible to ensure the smooth and the ability to move goods and services in bulk is a rail transportation.

From these considerations, the Government of the Republic of Indonesia in the Long Term Development Plan, set railway development plan to become the backbone of freight and urban passenger transport so that it can be one of the main drivers of the national economy. Implementation of an integrated national railway transport with other modes of transport can improve the efficiency of the national economy. Therefore, the national railway operation in the future should be able to be an important part in the structure of the national economy.

The Indonesian government to see that the market share of rail transport in the future is promising. It is estimated that the number of trips of people and goods using railway mode in 2030 is approximately 929.5 million passengers person / year and goods around 995.5 million tons / year, including traveling people using the railway mode on the island of Sulawesi is estimated at 15.5 million person / year and the number of trips of goods is estimated at 27 million tons / year.

Therefore, the Indonesian government established that one of the targets of the master plan of the national railways is the construction of railway networks in Sulawesi, which is expected to connect the regions or cities that have the potential transport of passengers and goods or products are large-scale high speed with the use of energy is very low and support, Sulawesi Railway Development plan linking 6 provinces in all regions of the island of Sulawesi.

The main issue is how to liberate the land owned by the community that will serve any railroad. Many farmland, gardens and ponds will pass the train line is owned by the community. Problems of land in Indonesia lately become a problem and often lead to protests from the community, and often cause casualties, on the one hand the people trying to defend his property because it is a source of life for them, while the government in this case the authorities tried to take the land by Indonesia Agrarian Law (1960) of article 18 says that "the public interest, including the interests of the nation, state, and public, the rights may be revoked by giving compensation appropriate and according the manner contemplated by law ".

Negotiations in the land acquisition process is usually a long process and protracted due to the absence of contact between the parties land owners and the government. In this process, the communication aspect is very important because people need information and understanding the purpose of the construction railroad track. Communication aims to provide an understanding and awareness to landowners in order to hand over land for the public interest, in this case used for the railway.

Note that prior to the release of land rights by the people, the government has made a wide range of communication activities (communication campaign) through the medium of television, newspapers, interpersonal communication, focus group discussion (meetings, gatherings, and dialogue), , and also through media internet (new media).

Communication campaign on the process of land acquisition will greatly assist in the smooth process of land restitution. In line with the goal of communication is done to influence the audience or recipient. According to Stuart in Cangara (2014), Influence or effect is the difference between what you think, feel, and carried out by the recipient before and after receiving the message. Influence is one element in the communication that is critical to 
determine the success or failure of communication we want. The influence can be said to be hit if the change $(\mathrm{P})$ which occurs at the receiver at the destination $(\mathrm{T})$ is desired communicator $(\mathrm{P}$ $=\mathrm{Q}$ ), or as a formula that has made Jamies in Cangara (2014), namely the influence (P) is determined by the source, messages, media, and recipients ( $\mathrm{P}=\mathrm{S} / \mathrm{P} / \mathrm{M} / \mathrm{P})$. Effect of changes can occur in the form of knowledge (knowledge), attitude (attitude), and behavior (behavior)

This paper to answer whether the dissemination of information campaigns on land acquisition railway lines to influence the knowledge, attitudes and behavior of the land owners, and what factors influence so that people are willing and not willing to give up their land for the construction of railway line?

\section{LITERATURE REVIEW AND RELATED}

Public communication campaigns encompass strategies for producing effects on the knowledge, attitudes, and behavior of large populations across a variety of domains, including political, pro-social, environmental, and health outcomes. Public communication campaigns can be broadly defined as purposive attempts to inform, persuade, or motivate behavior changes in a relatively well-defined and large audience, generally for noncommercial benefits to the individuals and/or society at large, typically within a given time period, by means of organized communication activities involving mass and online/interactive media, and often complemented by interpersonal support. The following sections provide selected annotated citations (books, book chapters, articles, and websites) in the general order of the stages involved in developing and implementing communication campaigns: General Overviews (texts, reviews, and guides), Journals, Theory, Social Marketing, Design (messages, media, and audiences), New Media, Formative Evaluation, Implementation (planning and managing), Campaign Issues (Community, Media Advocacy), Health (health issues), HIV/AIDS, Nutrition (including obesity), Drugs (drugs and alcohol), Smoking, Human Rights, Environment, and Evaluation. http://oxfordindex.oup.com/view/10.1093/obo/9780199756841-0055

Campaign objectives should be SMART: specific, measurable, achievable, realistic and timely. Clarifying what SMART means in precise terms really helps managers understand and produce good effective objectives. So here it is, the definition of SMART. Specific, in the context of developing objectives means that an observable action, behavior or achievement is described which is also linked to a rate, number, percentage or frequency. Measurable, this is very simple. A system, method or procedure has to exist which allows the tracking and recording of the behavior or action upon which the objective is focused. Achievable, the objectives that are set with people need to be capable of being reached. Relevant, this means two things; that the goal or target being set with the individual is something they can actually impact upon or change and secondly it is also important to the organization.

Time based, in the objective somewhere there has to be a date (Day/Month/Year) for when the task has to be started (if it's ongoing) and/or completed (if it's short term or project related). http://www.rialtoconsultancy.com/pdfs/reports/.

In the connection of the railway transport development, it has many benefits, especially for developing countries. World history shows that countries in the development stage to give great attention to the construction of railway. In the 19th century, when America opens its Western region (the Wild West) railway development has an important role. Until the US bringing in labor from China. 
Railway construction allows the opening of vast areas to participate in economic activities so as to improve the welfare widely as well. The production of the area that was once limited to marketing, with the railway can be marketed in a much wider area and in a much larger volume. The local people are also more freely traveling anywhere with a much easier and cheaper. It continues to grow as the country becomes industrialized countries, as seen in Europe and Japan. Railway transport logistics proved superiority of their significance in the nation. In addition, since the beginning of the railway has the role of a military strategy which is very important, where it is proven in the Civil War (Civil War) in the US. The mobilization plan designed by German General Staff to face World War I and II, a lot depends on the role of railway effective; It is important for the transportation of troops and transport people and goods.

Railway development also provide numerous employment opportunities, It is very useful for nations that need to overcome poverty. This is one reason why China is now so great attention to railway consruction. Created a lot of job opportunities when building new networks as well as in operating trains. China with a population of 1,300 million, and the number is still poor, is very interested in providing the employment opportunities.

\section{RESEARCH METHODS}

This study took place in Barru as one of the areas traversed line Sulawesi railway transportation programs in Indonesia. The sampling method to be the respondent is done by using a random sampling stratifileld with Slovin formula is:

$$
n=\frac{N}{1+N e^{2}}
$$

with a total sample of 100 people from 899 the number of existing population with an error rate of 10 percent or 0.1 .

This study has two variables, namely the Independent Variable (X) and the Dependent Variable (Y). Independent variables are often also referred to as variable stimulus, predictors or antecedent. Independent variables that affect or be cause changes of dependent variables related. The dependent variable is often also referred to as the output variable, criteria, consequential or dependent variable. The dependent variable is the variable that is affected or which become due for their independent variables.

In this study, the independent variable $(\mathrm{X})$ is a media dissemination of information, namely the mass media, interpersonal communication and Communications Group. The mass media used is Television (X1), Newspaper (X2), the Online Media/Internet (X3), Information from others/Interpersonal Communication (X4) and the Group Communications (X5). The dependent variable (Y) of the study was the effect of the dissemination of information as Knowledge (Y1), Attitude (Y2) and Behavior (Y3). 
Table 3.1. Variable Operationalization

\begin{tabular}{|c|c|c|c|}
\hline Variables & Dimension & Indicators & $\begin{array}{l}\text { Measure } \\
\text { ment }\end{array}$ \\
\hline \multirow{5}{*}{$\begin{array}{l}\text { Information } \\
\text { Dissemination }\end{array}$} & 1.Television & \multirow{5}{*}{$\begin{array}{l}\text { - intensity of message } \\
\text { - Acceptance message } \\
\text { - Use of Languages } \\
\text { - Clarity of message }\end{array}$} & \multirow{5}{*}{$\begin{array}{l}\text { Likert } \\
\text { Scale }\end{array}$} \\
\hline & 2.Newspaper & & \\
\hline & 3.Internet & & \\
\hline & $\begin{array}{l}\text { 4. Interpersonal } \\
\text { Communication }\end{array}$ & & \\
\hline & $\begin{array}{l}\text { 5. Group } \\
\text { Communication }\end{array}$ & & \\
\hline \multirow[t]{3}{*}{$\begin{array}{l}\text { Effects Changes } \\
\text { in land owners }\end{array}$} & Knowledge & $\begin{array}{l}\text { - Knowledge of land } \\
\text { acquisition } \\
\text { - Understanding of land } \\
\text { acquisition }\end{array}$ & \multirow[t]{3}{*}{$\begin{array}{l}\text { Likert } \\
\text { Scale }\end{array}$} \\
\hline & Attitude & $\begin{array}{l}\text { - Approved the release of } \\
\text { land ordinance } \\
\text { - response to the } \\
\text { compensation } \\
\text { information }\end{array}$ & \\
\hline & Behavior & $\begin{array}{l}\text { - willingness to release } \\
\text { land } \\
\text { - participation in the } \\
\text { dissemination of } \\
\text { information }\end{array}$ & \\
\hline
\end{tabular}

The instrument used in this study is a questionnaire by using a rating scale. Rating scale measurements with more flexible is not limited to the measurement of attitudes but also to measure respondents' perceptions of other phenomena, such as a scale to measure the socioeconomic status, institutional, knowledge, ability to process activities etc.

Before the questionnaire used first performed validity and reliability test. Validity test is used to determine how strong the relationship between one variable with another variable, while the reliability test is used to obtain results that are not misleading, and free from measurement error.

\section{Data Analysis Unit}

\section{DATA ANALYSIS IS DONE IN TWO WAYS}

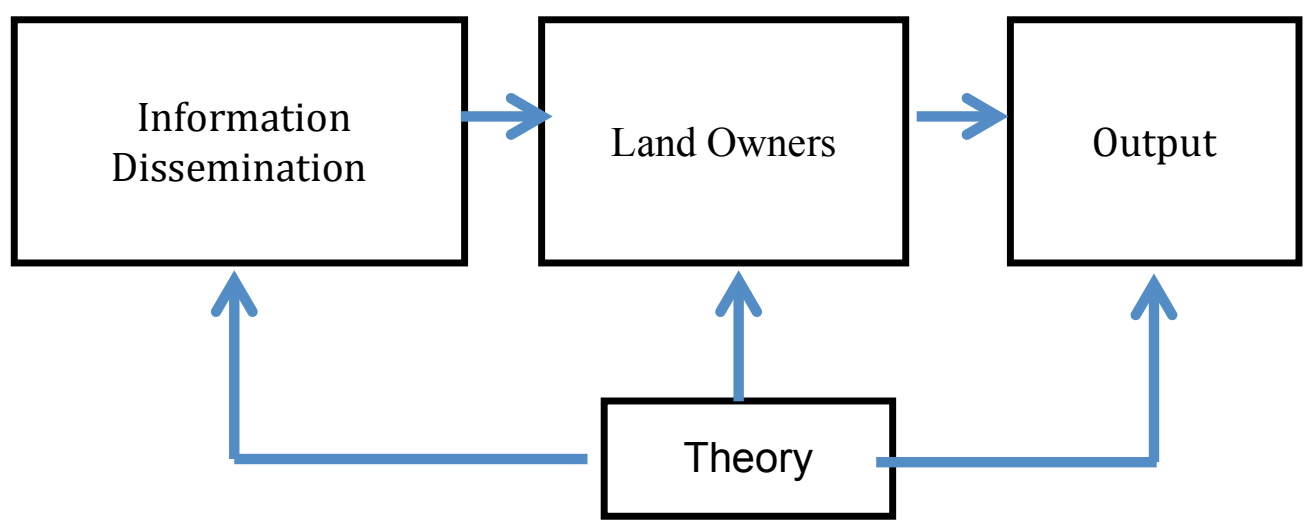




\section{Test Instruments Research and Data Analysis Techniques \\ Test Instruments Research}

The research instrument is measuring the social and natural phenomena. It is also said to be a tool used to measure the natural and social phenomena are observed (Sugiyono, 2014: 103).

The instrument used in this study is a questionnaire. The questionnaire contain a number questions of information dissemination on knowledge, attitudes and behavior of land owners using a rating scale in the process of land acquisition for the construction of a railway. Rating scale measurements with more flexible is not limited to the measurement of attitudes but also to measure respondents' perceptions of other phenomena, such as a scale to measure the socio-economic status, institutional, knowledge, ability to process activities etc.

Before the questionnaire used as an instrument of the first tested:

\section{Test Validity}

Validity test is used to determine the validity of a kuesioner. The testing process is done by analyzing each question on the questionnaire for each dimension. The validity of the test is useful for determining a quantity that expresses how strong the relationship of a variable with another variable.

\section{Test reliability}

Reliability testing of a number of questions in the questionnaire done that the data obtained from the measurement results when processed obtaining appropriate and avoid questionnaires error. A question to be reliable if someone answers to questions are consistent or stable over time. If reliable then the question can be measure the concepts. The measurement is considered as a means of data collection and free from measurement error. Reliability testing is important because it supports the formation of validity.

\section{DATA ANALYSIS TECHNIQUES}

After doing the research data collection, the data analysis by quantitative method and then encoding of data to unify it. Data analysis techniques used in this research was the analysis of the relationship (correlation) to determine the degree of correlation between the variables.

\section{Normality Test}

It is used to test the normality of the research data before testing hipotesis. The normality test is an attempt to determine whether the variable data possessed a population approaching normal distribution or not. The formula test for normality using the method of Chi-Square Test or X2 for Normal Distribution Goodness of fit using observation data deviation summation approach each class with the expected value.

$$
X^{2}=\sum \frac{\left(O_{i}-E_{i}\right)}{E_{i}}
$$

Where :

$\mathrm{Oi}=$ Value observations

$\mathrm{Ei}=$ expected value / expectancy, size class intervals based on normal

table multiplied by $\mathrm{N}$ (total frequency) (pi x N)

$\mathrm{N}=$ number of digits in the data (total frequency) 


\section{Correlation Analysis}

Correlation analysis is useful for determining a quantity that expresses how strong the relationship of a variable with another variable. Simbol of the magnitude of the correlation was $r$ (read rho) is called coefficient of correlation analysis. This study is used to describe the degree of relationship between the independent variable with the dependent variable.

The formula used to calculate the correlation coefficients as follows (this formula is also called the Pearson Product Moment)

$$
\begin{gathered}
\mathrm{r}= \\
\sqrt{\left\{\mathrm{n} \Sigma \mathrm{x}^{2}-(\Sigma \mathrm{x})^{2}\right\}\left\{\mathrm{n} \Sigma \mathrm{y}^{2}-(\Sigma \mathrm{y})^{2}\right\}}
\end{gathered}
$$

where :

$\mathrm{n}=$ Number of data pair $\mathrm{X}$ and $\mathrm{Y}$

$\Sigma \mathrm{X}=$ Total Number of variable $\mathrm{X}$

$\Sigma y=$ Total Number of Variable $Y$

$\Sigma \mathrm{x} 2=$ Square of Total Total Variable X

$\Sigma y 2$ = Square of Total Total Variable

$\mathrm{Y} \sum \mathrm{xy}=$ Result Multiplication of Total Number of variable $\mathrm{X}$ and variable $\mathrm{Y}$

\section{Regression Analysis}

Regression analysis is a technique for building equation and use these equations to make predictions. In this study will be used multiple regression analysis to predict or test the effect of independent variable to the dependent variable. When the score of the independent variables are known then the score of the dependent variable can be predicted magnitude. Regression analysis can also be performed to determine the linearity of the dependent variable with the independent variable. By using the equation:

$$
\mathrm{Y}=\mathrm{a}+\mathrm{bX} 1+\mathrm{bX} 2 \ldots+\mathrm{bXn}
$$

where :

$\mathrm{Y}=$ the dependent variable

$\mathrm{a}=$ constant regression

$\mathrm{b}=$ regression coefficient

$\mathrm{x}=$ value of independent variables

$\mathrm{n}=$ number of independent variables

Data and information obtained will be processed using the application Statistic Product and Service Solutions (SPSS version 18). Furthermore, after obtaining the data processed from SPSS to answer the problem formulation then made pathways such as image analysis 3.2

Analysis of the data is managed like in figure 3.1. the data focuses on the dissemination of information about land acquisition rail against the knowledge, attitudes and behavior of landowners in Barru. This study uses a quantitative research approach.

Population according Sugiyono (2014), is a generalization region consisting of the object/subject that has certain qualities and characteristics defined by the researchers to learn and then drawn conclusions. The population in this study were all land owners in railway line at Barru Regency. Total population in this study were 899 people. To determine the amount of a known amount of sample population used the formula Slovin. Samples according Kriyantono 
(2014) is part of a number of characteristics of the population. The sampling technique used stratifileld random sampling.

\section{Location}

\section{RESEARCH METHOD}

Location studies conducted in Barru traversed railway line and has land release process, in South Sulawesi Province, Indonesia.

\section{Data Source}

The data used are primary data and secondary data. According to Siregar (2016), the primary data is data collected by researcher directly from the first source or object of research. Secondary data is data that is published or used by non processing. Primary data in this study comes from the land owners railway line, while the secondary data obtained from various sources related to this research theme.

\section{Data Collection Technique}

Data collection techniques according Sugiyono (2014) is the most strategic step in the study, because the main goal of the study is to get the data. Data collection techniques that will be used in research questionnaires. Questioner is a technique of data collection is done by giving a set of questions or a written statement to the respondent. The list of questions that had been prepared previously propagated in which each question is provided the alternative answers, so that respondents only have to choose one of the alternative answers were considered to correspond to reality. The questionnaire is based items and the method used is Likert's Summated Rating. In this Likert scale, containing the alternative answers each question with gradations from positive to negative.

\section{Research Variable}

The study variables according to Sugiyono (2014) was everything any form defined by the researchers to be studied in order to obtain information about it then drawn conclusions. Theoretically variables can be defined as an attribute of a person or object that has a variation from one person to another person or object with another object. This study has two variables, namely the Independent Variables and Dependent Variables

Independent Variable $(\mathrm{X})$ is often also referred to as variable stimulus, predictors, antecedent that affect or be cause changes of dependent variables related. In this study, the independent variable $(\mathrm{X})$ is a media used to disseminate of information, namely the mass media, interpersonal communication and group communications. The mass media consist of Television (X1), Newspaper (X2), the Internet (X3), and other channel was used ; interpersonal communication (X4) and the group communication (X5).

Dependent Variable (Y) often referred to as the output variable, criteria, or consequential. The dependent variable is the variable that is affected or which become due for their independent variables. The dependent variable (Y) of the study was the effect of the dissemination of information as knowledge (Y1), attitude (Y2) and behavior (Y3)

\section{Effect of information dissemination to Knowledge}

\section{RESEARCH RESULT}

From the results of the study were processed using SPSS 18 showed that the influence of the communications media in aggregate consists of TV, Newspapers, Internet, Interpersonal 
Communication, and Group Communication of the knowledge land owners in railway line amounted to $72.2 \%$.

To determine the effect of partially used path analysis with the path diagram as shown below:

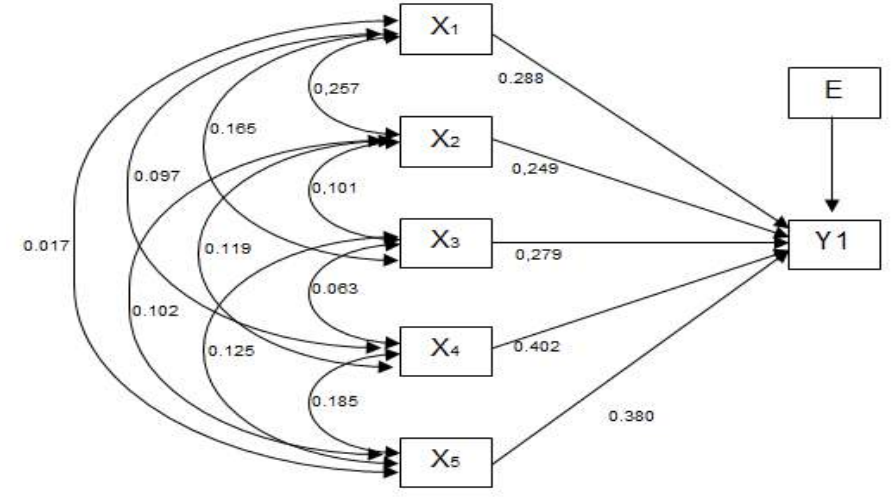

Figure 1. Line influence X1, X2, X3, X4, X5 to Y1

To calculate the effect is proportional by summing the direct influence of each variable and its indirect influence. To calculate the direct impact is to the equation: $=(P Y X n)(P Y X n)$ used for the indirect effect equation $=(\mathrm{PYXn})(\mathrm{rX} 1 \mathrm{X} 2)(\mathrm{PYX} 2)$

The values for the above equation is obtained from the results if the data using SPSS 18 (see table 1), so the result was calculated as follows: Influence of television on knowledge by 0087 , or $8.7 \%$, Newspaper of 0109 , or $10.9 \%$, internet amounted to 0.116 or $11.6 \%$, interpersonal communication of 0218 or $21.8 \%$, and the group communication of 0196 or $19.6 \%$. Media greatest effect on knowledge than Interpersonal Communication and Group Communication.

\section{Effect of information dissemination to Attitudes}

From the results of the study were processed using SPSS 18, shows that the influence of communication media on attitudes in aggregate consists of TV, Newspapers, Internet, Interpersonal Communication and Group Communication on the attitude of land owners in railway line amounted to $71.5 \%$

To determine the effect of partially used path analysis with the path diagram as shown below.

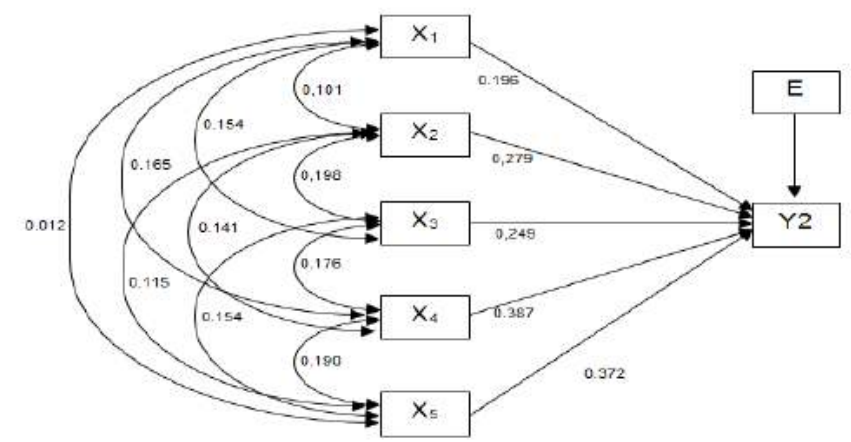

Figure 2. Diagram Line influence X1, X2, X3, X4, X5 to Y2

To calculate the effect is proportional by summing the direct influence of each variable and its indirect influence. To calculate the direct impact is to the equation: = (PYXn) (PYXn) used for the indirect effect equation $=(\mathrm{PYXn})(\mathrm{rX} 1 \mathrm{X} 2)(\mathrm{PYX} 2)$. 
The values for the above equation is obtained from the results if the data using SPSS 18 (see table 2), in order to obtain the results of the calculation as follows: Television is influence by 0064 , or $6.4 \%$, Newspaper of 0121 , or $12.1 \%$, Internet for 0114 , or $11.4 \%$, Interpersonal Communication 0221 or $22.1 \%$, and Group Communication for 0193, or 19.3\%.

\section{Effect of information dissemination to Behavior}

From the results of the study were processed using SPSS 18 shows that the effect of the media compound consisting of TV, Newspapers, Internet, interpersonal communication, and group communication on the behavior of land owners is $61.5 \%$.

To determine the effect of partially used path analysis with the path diagram as shown below:

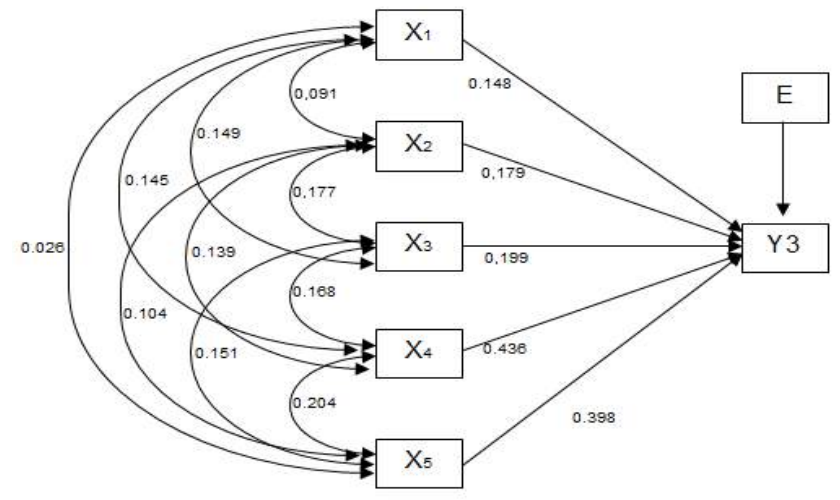

Figure 3. Line magnitude of the effect of X1, X2, X3, X4, X5 to Y3

To calculate the effect is proportional by summing the direct influence of each variable and its indirect influence. To calculate the direct impact is to the equation: $=(P Y X n)(P Y X n)$. To use the indirect effect equation $=(\mathrm{PYXn})(\mathrm{rX} 1 \mathrm{X} 2)(\mathrm{PYX} 2)$

The values for the above equation is obtained from the results if the data using SPSS 18 (see table 3), so the result was calculated as follows: Medium of television to influence the behavior of 0.039 or $3.9 \%$. newspaper of 0058 , or $5.8 \%$, internet for 0078 , or $7.8 \%$, Interpersonal Communication of 0260 , or $26.0 \%$, of group communication of 0215 or $21.5 \%$.

Total influence of media on behavior smaller than the influence attitudes and knowledge shows that changes in knowledge and attitudes are not always the same influence on behavior. However, knowledge and attitude is very important in shaping a person's behavior (overt behavior). A person's behavior based on the knowledge, will be more lasting than the behavior of someone who is not based on knowledge.

\section{Other factors that influence the process of land release}

The process of land acquisition for the construction of a railway line in Barru first phase has been completed. Territories included in the program's first phase consists of two sub-district Barru regency been completed. For the land procurement process ran smoothly without any significant obstacles.

From the results of this study found several factors that influence the process of land acquisition for the construction of the railway line, which is a factor in the public interest, the government program, understanding of religion, the compensation value, and a sense of pride with their government. 
The public interest factors, there are 45 of 100 respondents answer that they are willing to give up their land because it will be used for public purposes. as long as they are not harmed. Factors government program, There are 23 respondents or $23 \%$ to release their land by reason of helping the government in the implementation of development programs.

Understanding of Religion, there are 12 respondents or $12 \%$ to release their land for religious understanding. Knowledge and understanding of the religious values by respondents were able to change attitudes and behavior. To factor the value of compensation, There are 10 respondents or $10 \%$ feel that the compensation given deems sufficient. This means that respondents with this answer may change their behavior when they feel that what is given by the government is sufficient.

The pride in the presence of the railway has also become one of the factors that influence the process of land acquisition. There were 9 (nine) persons or $9 \%$ of respondents to answer because they feel proud of their trains that will operate on their country. They feel that the presence of trains its region is not left behind again from the island of Java and Sumatra in terms of transportation. They also felt the trip to capital city of province or to other areas easier.

\section{DISCUSSION}

Based on the research that the dissemination of information on land acquisition railway lines created among land owners through various media with the purpose of holding the titles to find out information on land acquisition as well as the effect on the attitude and behavior of land owners. Among the media and communication channel as used to disseminate of information, respondents were affected by successively as follows.

\section{Television}

By using television media dissemination of information not only very knowledgeable, but also quickly and simultaneously. Television in the task as disseminators of information, educate, entertain, social control, should be able to convey the message that people obtain information that is clear, complete, honest, ethical, and moral and objective. The results showed that information via television can give very little effect on the change in knowledge, attitude, and behavior of land owners. Just as newspapers, television nature also gave information is oneway, meaning its made less allow for dialogue between communicators with audience. In addition, because the intensity is very low viewership.

\section{Newspaper}

One of the media that provide information to land owners in railway line is a newspaper. The results showed that information through newspapers also effected changes in knowledge, attitudes, and behavior of land owners, although the effect is small. This is because the information in newspapers is one-way, meaning its made less allow for dialogue between communicators with readers. In addition, because the respondents do not subscribe to a newspaper.

\section{New Media (Internet)}

Information through new media here is the message or information acquisition railway lines obtained through the mass media or online news. According to Ramli (2012) online media (internet) is a mass media presented online at the web site (website) internet. The results showed that information via online media or internet can also give effect to changes in knowledge, attitudes, and behavior of land owners although the effect is small. Advantages of 
online media as a provider of a wide range of information very quickly not be fully utilized by the respondents because of limited ability to access information through the internet.

\section{Interpersonal Communication}

Based on the results of the research showed that interpersonal communication is a communication medium greatest effect on knowledge, attitudes and behavior among other communication media. This is in line with what Effendy (1999) noted that interpersonal communication is the communication between two or more people through face to face or through the media. Interpersonal communication is considered a type of effective communication to change the attitudes and behavior of people because of the personal contact that allows communicators to know, understand and master frame of reference, physical and mental condition ofcommunication partisipants, the atmosphere at the time of communication, and feedback directly.

According to Paul Lazarsfield and his colleagues were doing research into how information and influence spread in the community. He stated that the information flow from the mass media to a certain opinion leaders in the community who provide information by talking to his colleagues (Littlejohn, 2014).

Two-step flow theory written Lazarsfield confirms that certain individuals are known as opinion leaders (opinion leaders) received information from the mass media and give it to his colleagues Each group has a leader of opinion, but these individuals are difficult to distinguish from other members of the group because of its leadership in the opinion is not a trait but a role taken by some individuals in certain situations.

\section{Group Communication}

Group communication between the government and land owners is focus group discussion (meetings) held in each village. Based on the results showed that in this focus group discussion between the government and the land owners gives big influence to change their knowledge, attitudes and behavior. This is understandable because at the time of focus group discussion occurs face to face meeting between the government with the land owners which individual can respond to each other.

According to Effendy (1999), a group communication is communication between a person and a group of people in face to face situations. These groups can be small can be big. But the number of people that belong to the big or small is not specified. In a small group communication allows the presence of opportunity for every member to give verbal feedback

Interpersonal communication and group communication is the most substantial influence on behavior change because it is more persuasive while mediated communication is more informative. This is in line with the said Effendy (1999) that the effectiveness and efficiency of media communication only in disseminating information. Effective and efficient in delivering a persuasive message is face to face communication as a frame of reference of audience can be known communicators, whereas in proces communication is directly feedback, in the sense of knowing the response or reaction communicator to members of group at that time.

This is in contrast to the communication through the media, newspapers and television that does not allow communicators to know the terms of reference of audiences targeted communication and feedback takes place not at the time. 
According to Cassandra in Cangara (2014) there are two models in the preparation of the message that is informative and persuasive messages. Model preparation of informative messages are directed at the expansion of knowledge and awareness of audiences. It is more simple, clear, and does not use a lot of jargon or terms that are less popular among audiences. Model preparation persuasive message has a goal to change perceptions, attitudes, and opinions audiences. Therefore the preparation of a persuasive message has a proposition. Proposition here is what is desired source to the receiver as a result of the message it conveys, meaning that every message created their desired changes.

From the research that has been discussed above, there are five factors that affect the process release of land for the construction of a railway line in Barru regency. The factors namely ; general interest, a government program, understanding of religion, the compensation value, and a sense of pride in the presence of a train. Public interest factors, government programs and understanding of religious influence in society in line with the thinking Goran Hadebro a Swedish professor (1982) in his book, Communication and Social Change in Developing Nation successfully develop communications media uses to twelve function (Cangara, 2014). Three of the twelve functions of the state that, (1). Communication functions fosters participation in decision making on matters concerning the interests of the people, (2). Communication functions to support the implementation of development programs in the field of economic, social and security in order to improve the welfare of society, (3). Communication serves to create a climate change by introducing new values to change knowledge, attitud, and behavior towards more modernization.

To factor the value of compensation, that people are willing to take off the ground due to the compensation value. This is consistent with the strategy to obtain compliance disclosed Gerald Marwell and David Smith in compliance with the theory that an exchange with something provided by the search terms of compliance. If you do what I want then I will give you something in return such as respect, approval, money, liability exemption and a pleasant feeling (Morissan 2013).

Based on the assumption that the exchange theory is often used in social theory, stating that people act to get something from others in exchange for other things. This model has an orientation on power. In other words, you will gain their compliance if you have enough resources to provide or not provide anything they want. According to Wheeles in Morissan (2013), the best way to classify messages in order to obtain compliance is based on the type of power used communicator when trying to get compliance from others.

Wheeles power forward three general types: (1) Power in terms of the ability to manipulate the consequences of a particular course of action (ability to manipulate the conseqwences of a certain course of action). (2) The power or ability to determine the position of one's relationship with others. Here the people in power who adapat identify certain elements of a relationship that can bring compliance. (3) The power or ability to determine the value of liabilities or both (to define values, obligation or both). Here someone has the credibility to tell others norms accepted or required actions.

Public interest, government programs, religious knowledge, the compensation, and pride is the influence that guide the behavior of land owners so that they are willing to release their land. According to Ruben \& Stewart (2013), Receipt of information involved and changing environmental messages into a form that can be used to guide behavior. The proces of receipt information contains three elements of selection, namely; perception, interpretation, and 
retention of information. There are various interpretations of the message information affects decisions and guide our behavior.

\section{Needs}

Among the most important factor and plays a role in the acceptance message is what we often refer to the need. Our most basic needs, as well as animals, are related to the presence of our physiological-food, shelter, a state of good physical and sexual needs. Basic needs can encourage behavior that we do. When their needs are met, our efforts to fulfill is a strong push in the acceptance and process. Needs or other motifs after covering basic needs of social contact. exploration and comprehension of reality, socialization, diversion, entertainment, and games, all of it is concerned with the welfare conditions of mental, psychological, social and our communication. Perhaps the most basic of these needs to be done to maintain and develop our identity and self-concept.

All of us want to see a positive feasible, desirable, competent, and honorable. Of course, there are differences between us, in terms of a certain quality which we expect to be our values. Some of us aspire to be seen as a creative smart, competent professionals, and succeed in the job. While for others, it might be more important if it can be shown by a religious man, an honest, honorable or empathetic. Some prefer to be admired alongside his leadership capacity, while others have been more honored if they could have the loyalty of followers and so on.

\section{Attitudes, Beliefs and Values}

Attitudes, preferences and the tendency of a person to a particular topic, belief related to the religion held by someone, that he gave up his land to be used for public purposes for the benefit and reward from God. While value is a term used in reference to the basic principles of our lives reasoning about what should be done and not done in relation to the environment and society. Person or situation also plays an important role for the activities and the proceeds of information.

\section{Goal}

Most of us, just paid attention to our needs, attitudes, beliefs, and values contrary we set goals we consciously. When someone decides to pursue a certain plan, career personal relationships, or personal challenges, that goal gives us direct attention to the various the necessary resources, leaving sources of outside information that we need. Getting the appropriate interpretation of the sources of information is a priority until the goal is achieved or revised a change of interest are often also imply changes in the information process.

\section{CONCLUSION}

Based on the analysis and discussion that has been raised previously about the effect of the distribution of information on land acquisition railway lines in conjunction with the knowledge, attitudes and behavior of land owners in Barru regency, then as the conclusion of the results obtained: The amount of influence the distribution of information to knowledge of land owners through television media by $8.72 \%$, the newspaper amounted of $10.90 \%$, the internet by $11.60 \%$, the interpersonal communication by $21.81 \%$, and through group communication by $19.62 \%$. Effect of information through the media against knowledge of land owners as a whole amounted to $72.20 \%$.

The amount of influence the distribution of information on the attitudes of land owners through the medium of television at 6:43\%, the newspaper by $12: 15 \%$, the internet by $11: 44 \%$, 
interpersonal communication by $22: 16 \%$, and through group communication by 19:30\%. Effect of information through the media on the attitudes of land owners as a whole amounted to $71.50 \%$.

The amount of influence the distribution of information on the behavior of land owners through television by $3.90 \%$, the newspaper to $5.86 \%$, the internet to $7.81 \%$, the interpersonal communication of $26.04 \%$, and the group communication of $21: 48 \%$. Effect of information through the media against behavior of land owners as a whole amounted to $65.10 \%$.

Factors that influence the process of land acquisition for the construction of a railway line in Barru is a general interest, a government program, understanding of religion, the compensation value, and a sense of pride with their train.

In the implementation process of the release of land for development or for the benefit of the public, the government should disseminate of information with more frequency, by utilizing the media as much as possible and invite community leaders and all the people involved in the release of land. Besides the content of the message should be clear. It also should expand community activities of a religious nature which basically adds to the knowledge and understanding of the religious values. And increasing the information dissemination of laws and regulations concerning the public interest that would increase knowledge and understanding of the values of public interest.

\section{References}

Cangara, Hafied (2014). Communication Planning and Strategies. Jakarta: Rajagrafindo Persada. Jakarta Effendy O.U. (1999). Introduction to Communication: Theory and Practice. Remaja Rosdakarya. Bandung Hadebro, Goran (2009) Communication and Social Change in Developing Nations; A Critical View. Economic Research Inst., Stockholm School of Economics : School of Journalism, University of Stockholm. Sweden.

Kriyantono R. (2014). Practical Techniques of Communication Research. PT. Fajar Interpratama Mandiri, Jakarta. Litlejhon, Stephen.W and Karen A. Foss. (2011). Theories of Human Communication, Waveland Press Inc. Long grove, Illinois.

Morissan. (2013). Communication Theory: Individuals up to Mass. Kencana, Jakarta

Ramli, A.S.M. (2012). Journalism Online, A Practical Guide Managing Media. Nuansa Cendekia, Bandung

Rice, Ronald E and William J Paisley. (1982). Public Communication Campaigns. Sege Publications. Baverly London.

Rice, Ronald E and Charles K. Atkin. (2011) Public Communication Campaigns, Research Guide Edited by Patricia Moy, ISBN: 9780199756841 Published online February 2011.

Ruben B.D and Stewart. (2014). Communication and Human Behavior. Kendall Hunt. Publishing Company, Dubuque, IA 52004-1840.

Siregar S. (2016). Descriptive Statistics for Research. Rajagrafindo Persada, Jakarta

Sugiyono. (2014). Qualitative and Quantitative Research Methods. CV Alfabeta. Bandung. 


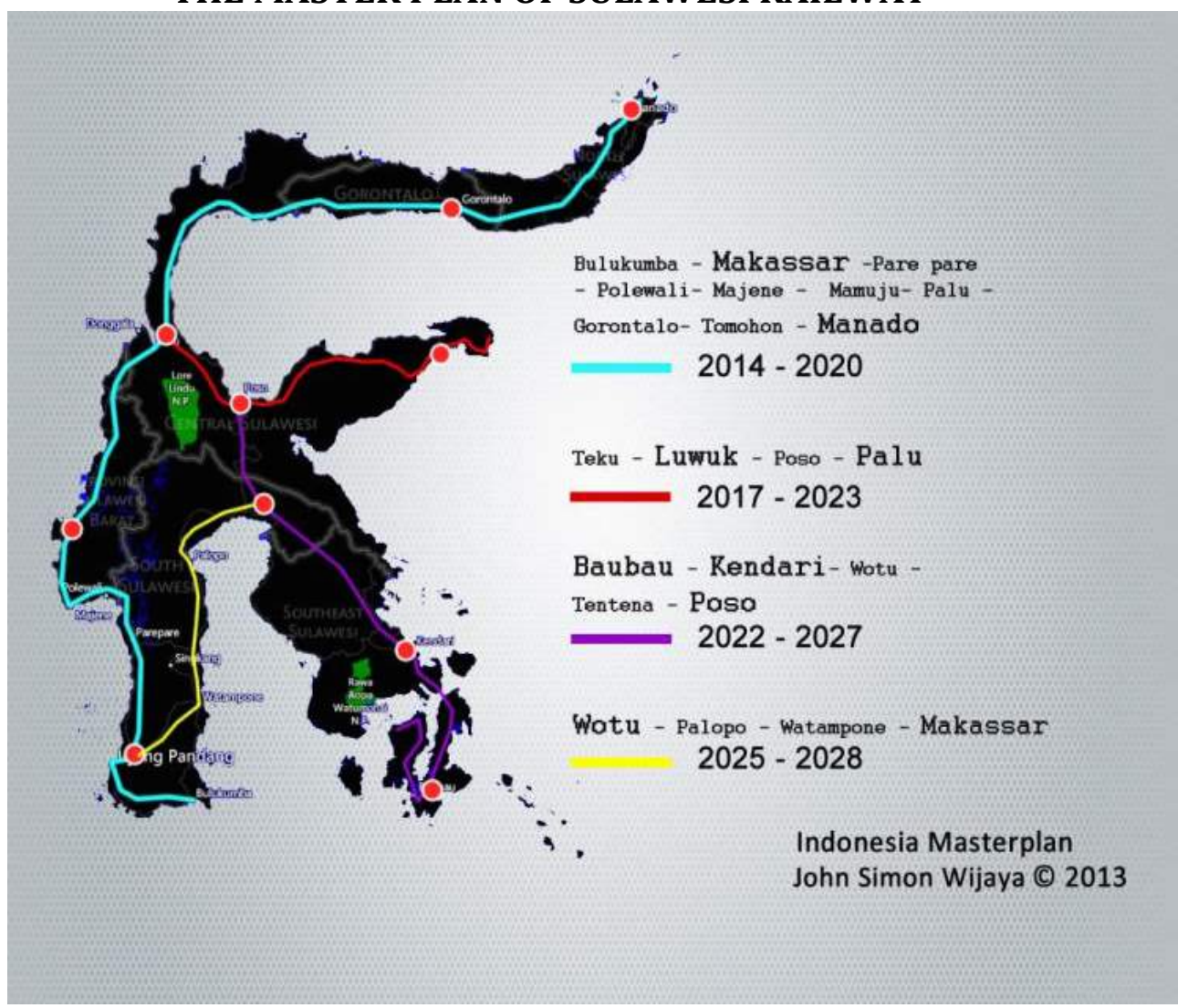

Table 1. Correlation knowledge with media information (results on the data with SPSS 18) Correlation

\begin{tabular}{|c|c|c|c|c|c|c|c|}
\hline & & Knowledge & $\begin{array}{c}\text { Televisio } \\
\mathrm{n}\end{array}$ & $\begin{array}{l}\text { News- } \\
\text { paper }\end{array}$ & Internet & $\begin{array}{c}\text { Inter- } \\
\text { persona } \\
\text { l }\end{array}$ & Group \\
\hline \multirow[t]{6}{*}{ Pearson Correlation } & Knowledge & 1000 & 228 & .249 & .279 & .402 & 380 \\
\hline & Television & .228 & 1.000 & .257 & .165 & .097 & .017 \\
\hline & Newspaper & .249 & .257 & 1.000 & .101 & .119 & .102 \\
\hline & Internet & .279 & .165 & .101 & 1.000 & .063 & .125 \\
\hline & Interpersonal & .402 & .097 & .119 & .063 & 1.000 & .062 \\
\hline & Group & .380 & .017 & .102 & .125 & 1.85 & 1.000 \\
\hline \multirow[t]{6}{*}{ Sig. (1-tailed) } & Knowledge & & .000 & .000 & .000 & .006 & 000 \\
\hline & Television & .000 & & .000 & .045 & .145 & .169 \\
\hline & Newspaper & .000 & .000 & & .203 & .134 & .352 \\
\hline & Internet & .000 & .045 & .203 & & .089 & .268 \\
\hline & Interpersonal & .006 & .145 & .134 & .089 & & .271 \\
\hline & Group & .000 & .169 & .352 & .268 & .271 & \\
\hline \multirow[t]{6}{*}{$\mathrm{N}$} & Knowledge & 100 & 100 & 100 & 100 & 100 & 100 \\
\hline & Television & 100 & 100 & 100 & 100 & 100 & 100 \\
\hline & Newspaper & 100 & 100 & 100 & 100 & 100 & 100 \\
\hline & Internet & 100 & 100 & 100 & 100 & 100 & 100 \\
\hline & Interpersonal & 100 & 100 & 100 & 100 & 100 & 100 \\
\hline & Group & 100 & 100 & 100 & 100 & 100 & 100 \\
\hline
\end{tabular}


Table 2. Correlation attitude with the media information

(results on the data with SPSS 18)

Correlation

\begin{tabular}{|c|c|c|c|c|c|c|c|}
\hline & & Attitude & $\begin{array}{c}\text { Televisio } \\
n\end{array}$ & $\begin{array}{l}\text { News- } \\
\text { paper }\end{array}$ & Internet & $\begin{array}{c}\text { Inter- } \\
\text { persona } \\
\text { l }\end{array}$ & Group \\
\hline \multirow[t]{6}{*}{ Pearson Correlation } & Attitude & 1.000 & .196 & .279 & .249 & .387 & .379 \\
\hline & Television & 196 & 1.000 & .101 & .154 & 165 & . 012 \\
\hline & Newspaper & .279 & 101 & 1.000 & 198 & .141 & .115 \\
\hline & Internet & .249 & .154 & .198 & 1.000 & 176 & .154 \\
\hline & Internorcon & .387 & .165 & .141 & .176 & 1.000 & 190 \\
\hline & $\begin{array}{l}\text { Group } \\
\text { Grorpersonal }\end{array}$ & .379 & .012 & .115 & .154 & .190 & 1.000 \\
\hline \multirow[t]{6}{*}{ Sig. (1-tailed) } & Attitude & & .000 & .000 & .000 & .006 & 000 \\
\hline & Television & .000 & & .000 & .045 & .145 & .169 \\
\hline & Newspaper & .000 & .000 & & .203 & .134 & .352 \\
\hline & Internet & .000 & .045 & .203 & & .089 & .268 \\
\hline & Interpersonal & .084 & .145 & .134 & .089 & & .271 \\
\hline & Group & .000 & .169 & .352 & .268 & .271 & \\
\hline \multirow[t]{6}{*}{$\mathrm{N}$} & Attitude & 100 & 100 & 100 & 100 & 100 & 100 \\
\hline & Television & 100 & 100 & 100 & 100 & 100 & 100 \\
\hline & Newspaper & 100 & 100 & 100 & 100 & 100 & 100 \\
\hline & Internet & 100 & 100 & 100 & 100 & 100 & 100 \\
\hline & Interpersonal & 100 & 100 & 100 & 100 & 100 & 100 \\
\hline & Group & 100 & 100 & 100 & 100 & 100 & 100 \\
\hline
\end{tabular}

Table 3. Correlation with the behavior of media information (results on the data with SPSS 18)

Correlation

\begin{tabular}{|c|c|c|c|c|c|c|c|}
\hline & & Behavior & $\begin{array}{c}\text { Televisio } \\
n\end{array}$ & $\begin{array}{l}\text { News- } \\
\text { paper }\end{array}$ & Internet & $\begin{array}{c}\text { Inter- } \\
\text { persona } \\
\text { l }\end{array}$ & Group \\
\hline \multirow[t]{6}{*}{ Pearson Correlation } & Behavior & 1.000 & .148 & .179 & .199 & .438 & .398 \\
\hline & Television & .148 & 1.000 & .091 & .149 & .145 & .026 \\
\hline & Newspaper & .179 & .091 & 1.000 & 177 & .139 & .104 \\
\hline & Internet & .199 & .149 & .177 & 1.000 & .168 & .151 \\
\hline & Interpersonal & .436 & .145 & .139 & .168 & 1.000 & .204 \\
\hline & Group & .398 & .026 & .115 & .154 & .190 & 1.000 \\
\hline \multirow[t]{6}{*}{ Sig. (1-tailed) } & Behavior & & .000 & .000 & .000 & .006 & 000 \\
\hline & Television & .000 & & .000 & .045 & .145 & .169 \\
\hline & Newspaper & .000 & .000 & & .203 & .134 & .352 \\
\hline & Internet & .000 & .045 & .203 & & .089 & .268 \\
\hline & Interpersonal & .119 & .145 & .134 & .089 & & .271 \\
\hline & Group & .000 & .169 & .352 & .268 & .271 & \\
\hline \multirow[t]{6}{*}{$\mathrm{N}$} & Behavior & 100 & 100 & 100 & 100 & 100 & 100 \\
\hline & Television & 100 & 100 & 100 & 100 & 100 & 100 \\
\hline & Newspaper & 100 & 100 & 100 & 100 & 100 & 100 \\
\hline & Internet & 100 & 100 & 100 & 100 & 100 & 100 \\
\hline & Interpersonal & 100 & 100 & 100 & 100 & 100 & 100 \\
\hline & Group & 100 & 100 & 100 & 100 & 100 & 100 \\
\hline
\end{tabular}

\begin{tabular}{lcccccc}
\hline & Television & Newspaper & Internet & Interpersonal & Group & Effects \\
\hline Knowledg & 0.087 & 0.109 & 0.116 & 0.218 & 0.196 & 0.722 \\
Attitude & 0.064 & 0.121 & 0.114 & 0.221 & 0.193 & 0.715 \\
Behavior & 0.039 & 0.058 & 0.078 & 0.260 & 0.215 & 0.651 \\
\hline
\end{tabular}

